University of Nebraska - Lincoln

DigitalCommons@University of Nebraska - Lincoln

Textile Society of America Symposium

Proceedings

Textile Society of America

2020

\title{
Artistic Philanthropy and Women's Emancipation in Early Twentieth-Century Italy, in the Life and the Work of Romeyne Robert and Carolina Amari
}

\author{
Maria Luciana Buseghin \\ mlbuseghin@gmail.com
}

Follow this and additional works at: https://digitalcommons.unl.edu/tsaconf

Part of the Art and Materials Conservation Commons, Art Practice Commons, Fashion Design Commons, Fiber, Textile, and Weaving Arts Commons, Fine Arts Commons, and the Museum Studies Commons

Buseghin, Maria Luciana, "Artistic Philanthropy and Women's Emancipation in Early Twentieth-Century Italy, in the Life and the Work of Romeyne Robert and Carolina Amari" (2020). Textile Society of America Symposium Proceedings. 1133.

https://digitalcommons.unl.edu/tsaconf/1133

This Article is brought to you for free and open access by the Textile Society of America at DigitalCommons@University of Nebraska - Lincoln. It has been accepted for inclusion in Textile Society of America Symposium Proceedings by an authorized administrator of DigitalCommons@University of Nebraska - Lincoln. 


\title{
Artistic Philanthropy and Women's Emancipation in Early Twentieth- Century Italy, in the Life and the Work of Romeyne Robert and Carolina Amari
}

\author{
Maria Luciana Buseghin \\ mlbuseghin@gmail.com
}

Between 1902 and 1904 Romeyne Robert conducted, with her friend Nathalie Smith Dana, a research across the territory, in museums and libraries, to find traditions and iconographic sources; on the basis of these studies, in 1904 she created a school-laboratory of embroidery in the Pischiello estate: the "Scuola Ricami Ranieri di Sorbello." In the school, the peasant women could learn a trade capable of emancipating them from working in the fields and from total subjection to fathers and husbands. Romeyne was also able to transmit to them savings and pension criteria by opening a bank or post office book. In addition, the school taught personal care and hygiene, necessary in daily life but also for cleaning in embroidery works that had to be carried out with precision, skill and industriousness; these characteristics were attested by a booklet with the history of the workers and their work.

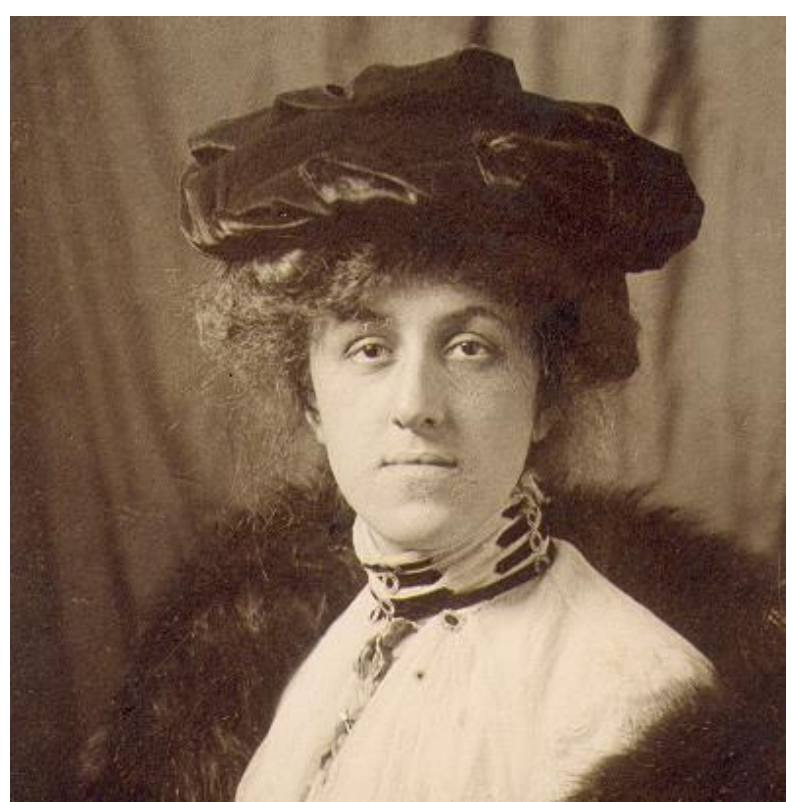

Romeyne Robert Ranieri di Sorbello (Morristow, 1878 - Perugia, 1951)

Fondazione Ranieri di Sorbello Archive

We know that in those same years, Romeyne frequented the Roman headquarters of the Italian Feminine Industries, a cooperative founded on May 22, 1903, in via Marco Minghetti, of which she was a shareholder and a great animator. Tryphosa B. Bates-Batcheller, an enterprising American lady who spent a few months in Rome in 1905 attending the Roman 
aristocracy, tells us about that refined salon for Italian and American ladies who are passionate about textiles:

Here are three of the most energetic workers in this society (the Countess Brazzà, the Marchesa di [sic] Viti de Marco, the Marchesa di Sorbello) all bearing long and noble Italian names; but we are proud to claim them as American women, who have gone into the Old World, and are not only a credit to the title that they bear, but an honor to the name of womanwood, for the energy and ability they have shown in advancing the conditions of the country which they have adopted as their own. ${ }^{1}$

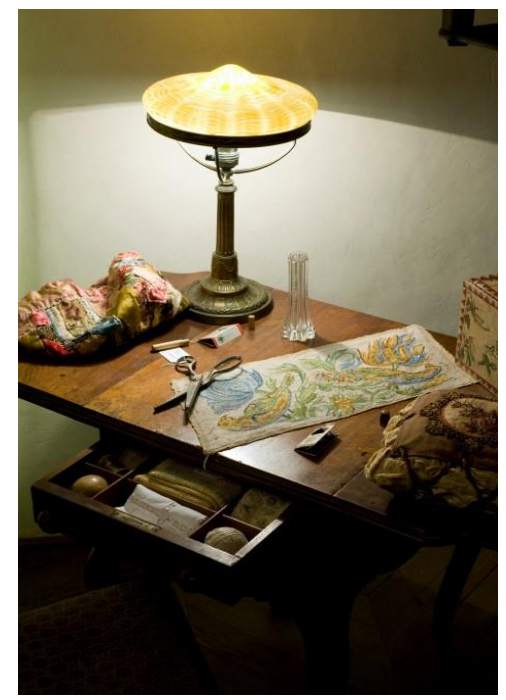

Worktable by Romeyne Robert who in 1904 founded the Ranieri di Sorbello Embroidery School in the Pischiello villa Fondazione Ranieri di Sorbello Archive

The school's specialty became the "Sorbello" or "Umbrian" stitch, a knotted stitch in relief created by the artistic director Carolina Amari who elaborated it from the ancient "Portuguese stitch," discovered by her in the collection of Edith Bronson (1861-1956, married with Conte Cosimo Rucellai in 1895) of the Women's Industries Committee of Florence.

The definition of "Sorbello stitch" corresponds to a complex of different stitches: knots, interlacing, scallops, knits, "witch," "curly," etc. The "Sorbello" was often combined with the needle "ivory stitch" with which connection inserts and finishes are worked. The Ivory stitch is also an ancient lace stitch of Arab origin, it reproduced the ivory grating motifs of the harems. The work was done with thick linen yarn, raw, cream, green, indigo, rust, or with cord and twine, on Umbrian canvas in hemp or linen, or mixed. Both the embroidery and the canvas bottom are very sturdy and do not fear washing or wear.

\footnotetext{
${ }^{1}$ Triphosa B. Bates-Batcheller, Glimpses of Italian Court Life. Happy Days in Italia Adorata. (Delhi, India: Facsimile Publisher, 2013/1 ${ }^{\text {st }}$ published 1906), 319-320.
} 

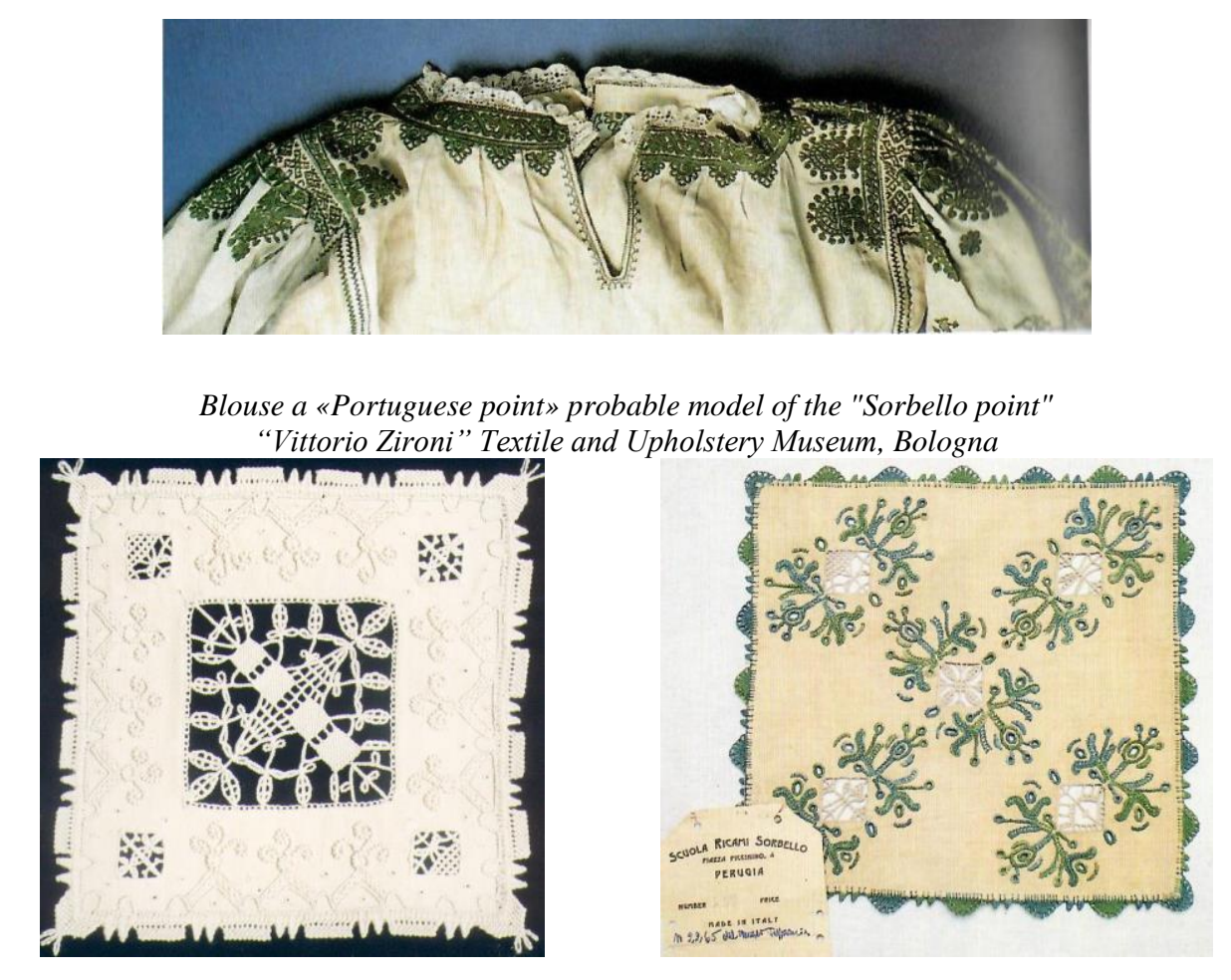

Centers embroidered with the different typologies of the "Sorbello stitch» category, with Aemilia Ars inserts and tassels Embroidery Collection Fondazione Ranieri di Sorbello, Palazzo Sorbello, Casa Museo, Perugia

The drawings, elaborated by Carolina Amari (Firenze, 1866 - Roma, 1942) and Romeyne Sorbello and inspired by medieval-Renaissance motifs; they were taken from ancient pieces, paintings or watercolors by Romeyne.

Romeyne's role, also in the artistic care of the School soon became increasingly important as in 1905 Amari founded in New York, with the help of Florence Colgate and Gino Speranza, the "School of Italian Industries," which operated until 1925. In the school-laboratory, young women emigrated from Italy made embroidery and lace which were exhibited for the first time in the exhibition organized in December 1905 to present to the American public the Italian embroideries; since 1908 the products of the school brought the brand "Sirena Amari."

Each artifact of "Scuola Ricami Ranieri di Sorbello" was made up of modules that made up a specific motif and each worker had her own specialization in an embroidery or lace module. The teacher Amelia Pompili (Montefalco, 1870 - 1970) taught stitches and gave drawings, yarns and canvas to the workers who made it at home by piecework. 


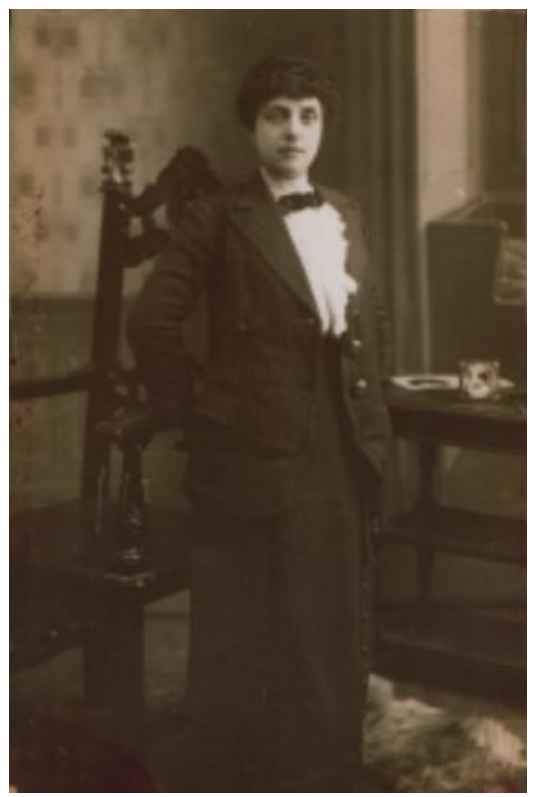

Amelia Pompili (Montefalco 8 febbraio 1870 - Foligno 1970) Fondazione Ranieri di Sorbello Archive

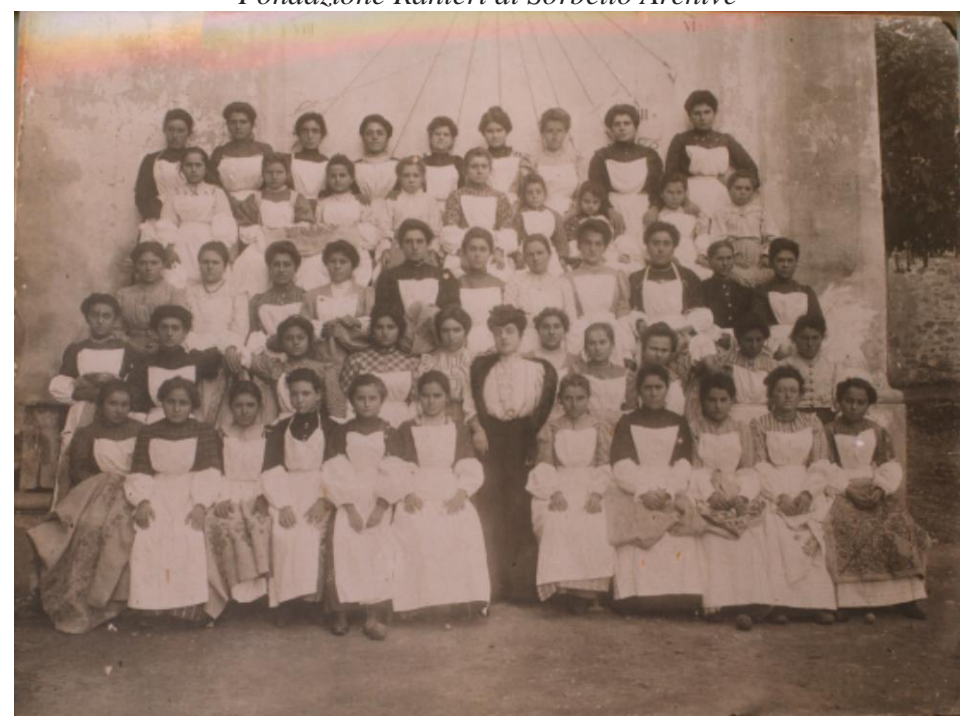

The workers of the School of Embroidery Ranieri di Sorbello with the teacher Amelia Pompili Villa del Pischiello Passignano sul Trasimeno, around 1910

Fondazione Ranieri di Sorbello Archive

In the School were produced all types of products and processes: centerpieces, saddles, tablecloths, coasters, curtains, handkerchiefs, pillows, bed blankets, handbags, brush holders and cosmetic bags; the photo on the left shows the numbers of the designs of two garments, as frequently done in the workshops of the time. Many textile artifacts were decorated at the corners with "tassels," copies of those found in the ancient collections, taking up the colors of the embroidery and increasing the effect. 


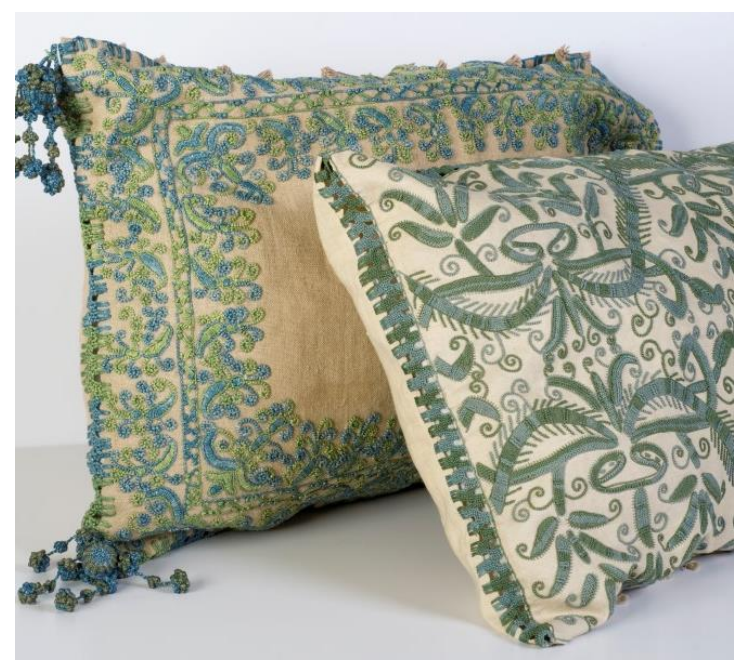

Cushions embroidered in different types of the «Sorbello stitch» category

Embroidery Collection Fondazione Ranieri di Sorbello, Palazzo Sorbello, Casa Museo, Perugia

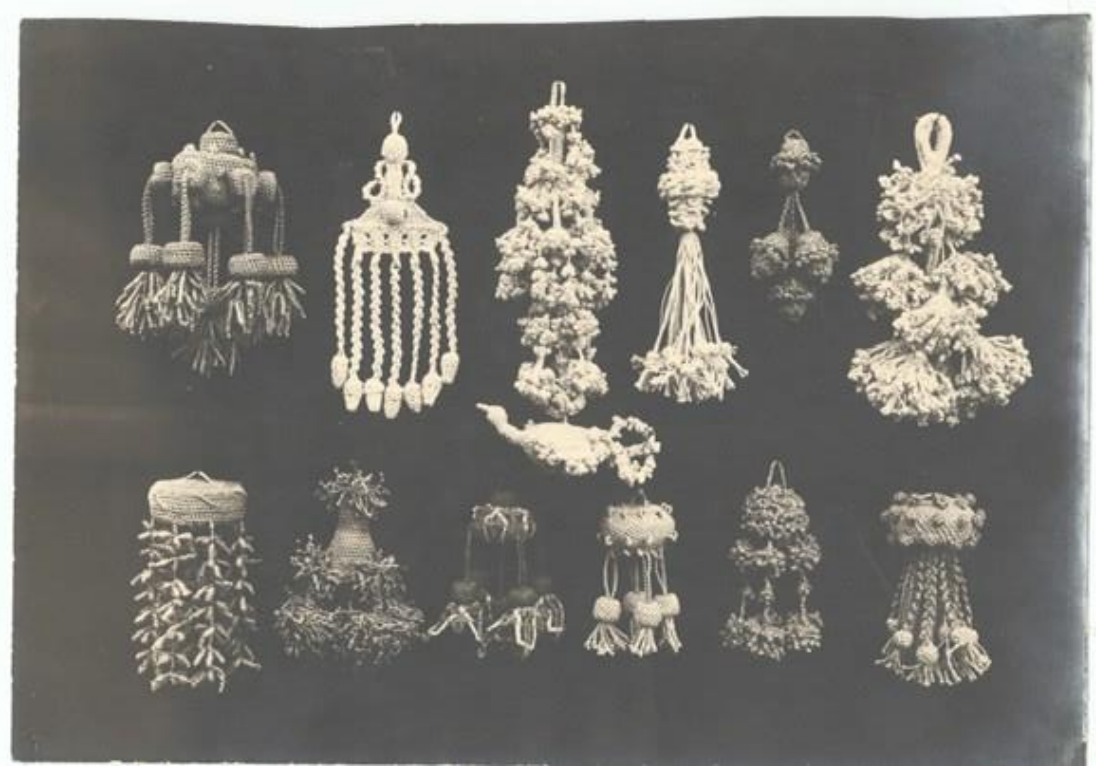

Series of "tassels", copies of those found in the ancient collections, which adorned the corners of the garments, taking up the colors of the embroidery and increasing its effect

Collezione Ragnotti Bellucci, deposito della Regione Umbria presso la Galleria Nazionale dell'Umbria

In 1911 the School participated in at least two exhibitions in Florence and Turin, where the gold medal was awarded to the teacher Pompili. 


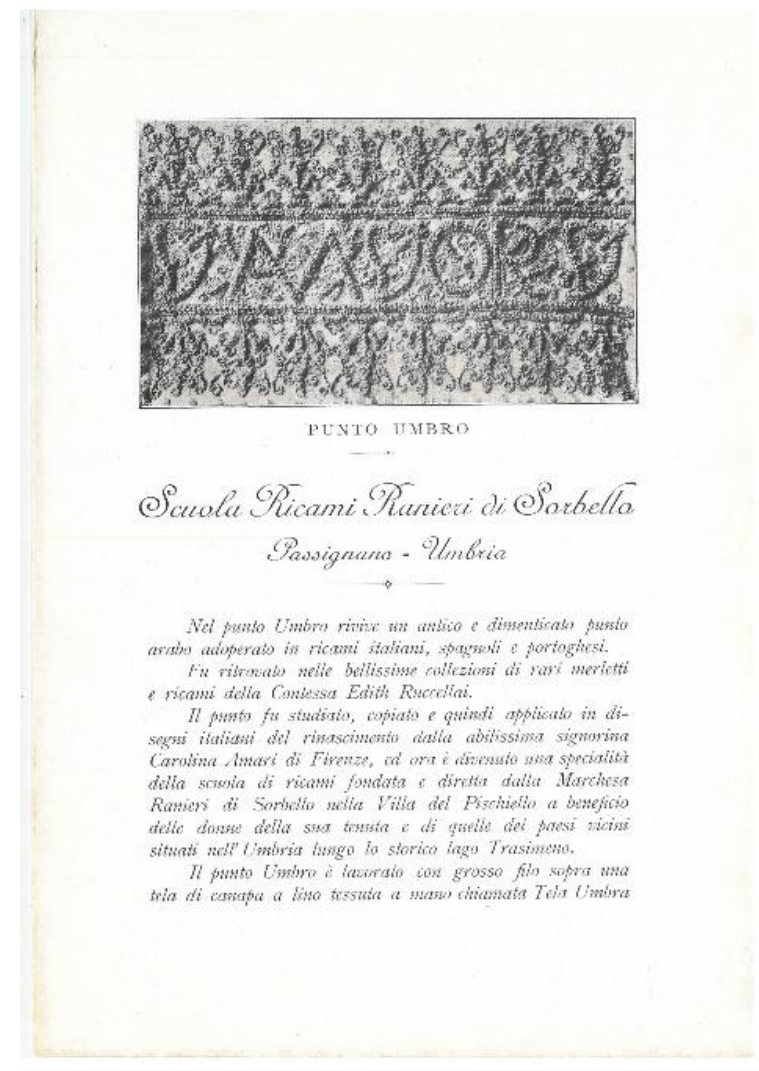

Advertising brochure of the Ranieri di Sorbello's Embroidery School (1910) made in occasion of «International Exhibition of the Industries and Work», Torino, 1911

Fondazione Ranieri di Sorbello Archive

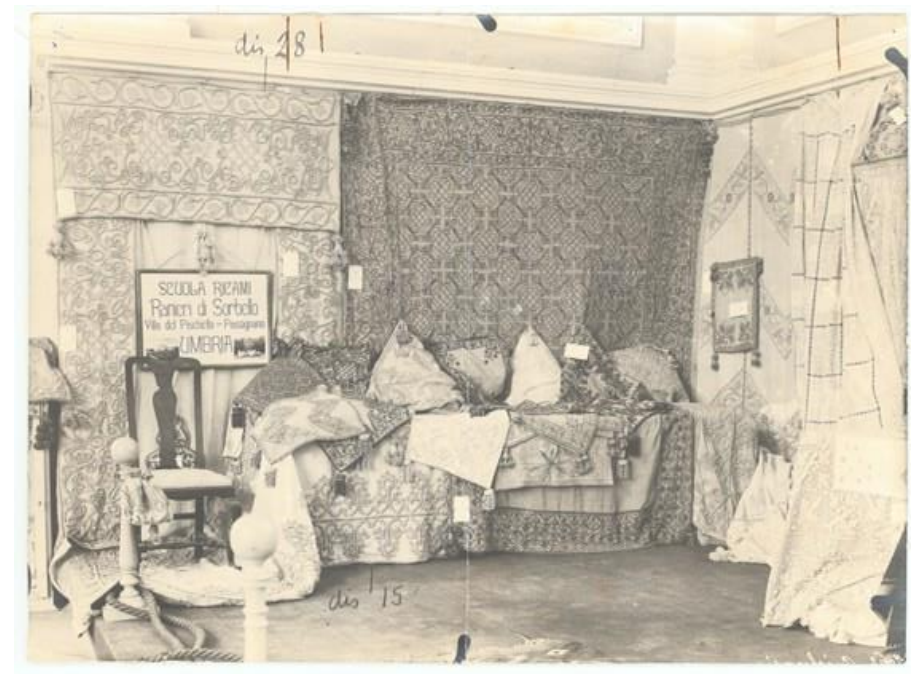

Exhibition of Scuola Ricami Ranieri di Sorbello with various types of products made with different techniques: centerpieces, saddles, tablecloths, coasters, curtains, handkerchiefs, pillows, bed blankets

Collezione Ragnotti Bellucci, deposito della Regione Umbria presso la Galleria Nazionale dell'Umbria

Romeyne, with some Perugian ladies, including Countess Maria Baldeschi and Baroness Vittoria Luce Danzetta, founded in the early 1920s the "Arti Decorative Italiane," a cooperative for the marketing of textile artifacts of 25 schools-workshops: each had its own specialization and all were under the artistic and technical direction of Carolina Amari. The artifacts were sold in a shop located in an ancient building in the center of Perugia; the 
cooperative closed at the end of 1929, while the Pischiello School resisted until 1934: both had to close due to financial difficulties resulting from the impossibility of exporting which had been their main source of income.

The cooperative had an "American" philosophy of production and life which included, among other things, the keeping of accounts with the "modern American system," already practiced in the "Scuola Ricami Ranieri di Sorbello" at Pischiello.

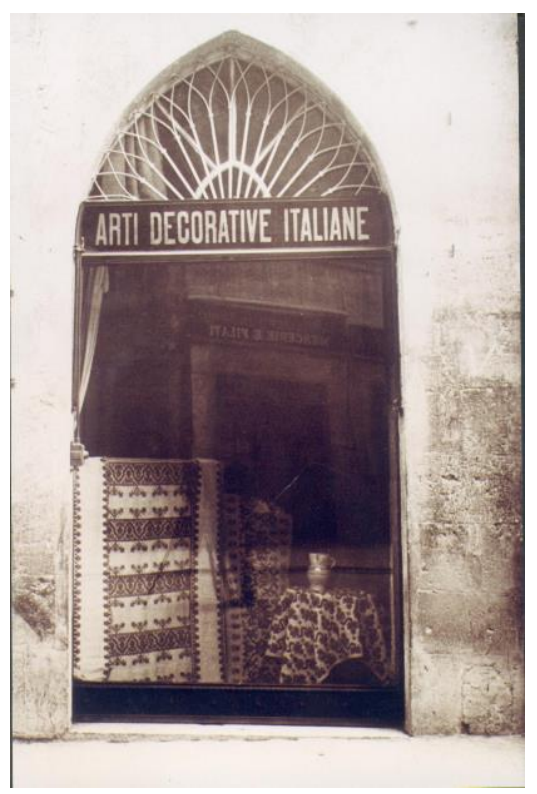

Shop of Arti Decorative Italiane, in Corso Vannucci 8, Perugia Fondazione Ranieri di Sorbello Archive

In 1921 Romeyne Robert Ranieri di Sorbello had it printed advertising booklet originally written in English to be sent to her customers in America. It contains the description of the most important schools and workshop.

The Amari School, personally directed by Carolina, was called the "mother of all the schools" because the samples and models for the other schools were first tried in this one. The characteristic work of Amari School was a "Italian embroidery of the Early Renaissance; which carries out on linen the decorative motive of Architecture, Carving and inlaid work of that best of period."

\footnotetext{
${ }^{2}$ Marilena de Vecchi, Valentina Costantini, The Romeyne Robert Ranieri di Sorbello School of Embroidery: a textile workshop for women embroideries in Umbria (1904-1934) (Perugia: Uguccione Ranieri di Sorbello Foundation, 2011), 11.
} 


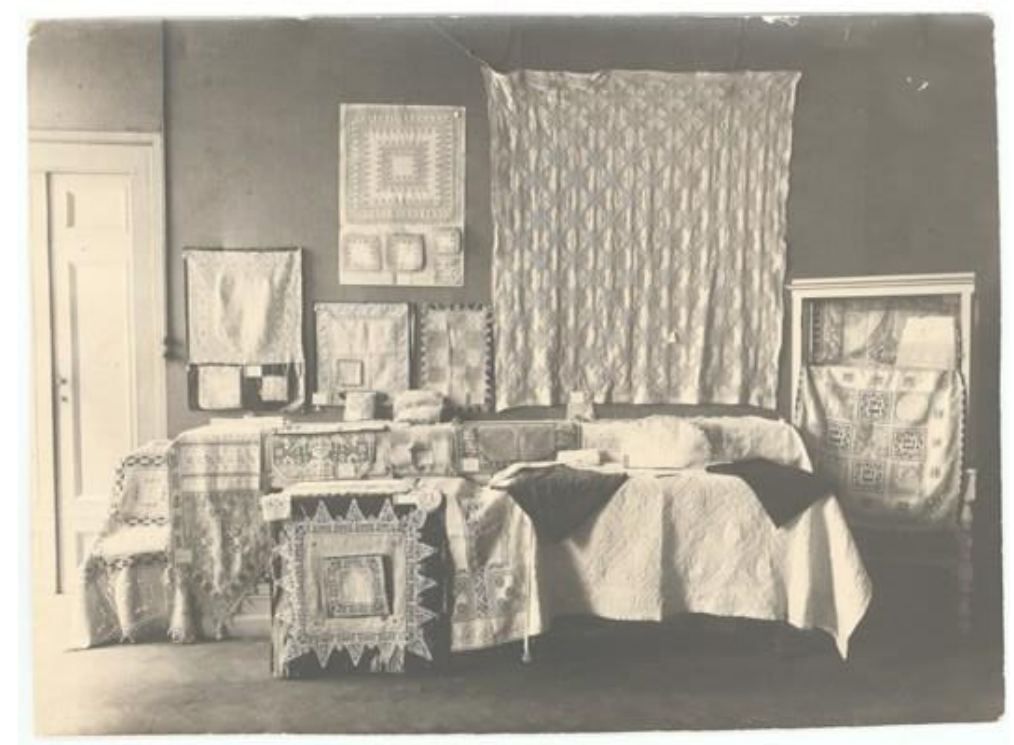

Exhibition of Arti Decorative Italiane with various types of products made with different techniques Collezione Ragnotti Bellucci, deposito della Regione Umbria presso la Galleria Nazionale dell'Umbria

Other important school was Panni Perugini that produced textiles woven in white linen and blue cotton, on imitation of a type of fabric produced "especially in Perugia, during all the Middle Age with characteristc designs of animal, towers, symbols, figures and inscriptions." I studied for many years these kind of textiles, coming to the conclusion that these are fabrics produced by mixed societies of Jews and Christians at least from the thirteenth to the sixteenth century, with a white linen background and indigo cotton decoration and with which tablecloths ("Perugia tablecloths") and furniture; this type of textile, also very present in the paintings of the most important painters of the time, was marketed throughout Europe and its finds can be found in many museums in Europe and America. ${ }^{3}$

Other textile productions (known at the time but now quite unknown), both in Abruzzo, were: Hand Woven linen of Introdacqua, where fabrics very similar to pulled thread embroidery Hand Woven Woolen Carpets of Castel di Sangro, woolen carpets with models of domestic rustic weaving, made with Italian hemp and pure wool, dyed with pure vegetable colors. ${ }^{4}$

Others schools they produced well-known embroideries that are still in use today as Punto Madama Caterina, quaint stitch done on loosely woven unbleached linen or on white transparent linen with designs of XVth-century; this kind ok work, very effective, was very much employed for curtains and bedspreads.

Other schools, besides Sorbello School, were: Buratto, Floral Filet, Baldeschi, Punto scritto, Punto Colonna, Bobbin Lace, Fringe Work, Volumnia, Primavera EmbroideryFlame stitch, Tiberina School, Lamporecchio School, Ansidei School, Tela buratto, Isotta School, Barocco, Punto Calabrese, Perugian Drawn Thread Work, Intagliatela.

\footnotetext{
${ }^{3}$ Maria Luciana Buseghin, Arte tessile ebraica in Umbria tra XIV e XX secolo: note di ricerca e ipotesi d'approfondimento, in Presenze ebraiche in Umbria meridionale dal medioevo all'età moderna. Atti della giornata di studi, Acquasparta, 12 giugno 2014, ed. Paolo Pellegrini (Foligno: Editoriale Umbra/Perugia, ISUC, 2017).

${ }^{4}$ De Vecchi, Costantini, The Romeyne Robert Ranieri di Sorbello School, 16-17.
} 


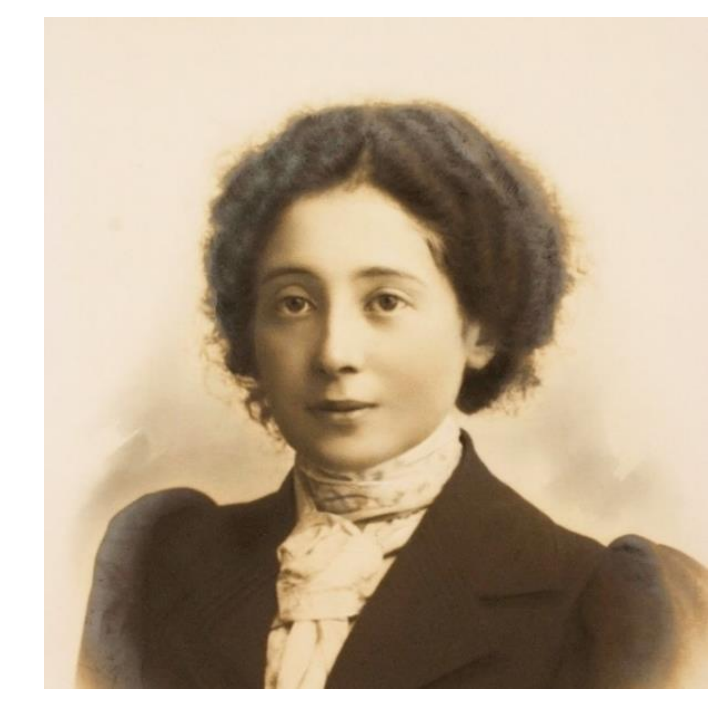

Alice Hallgarten Franchetti (New York, 1847 - Leysin, 1911) Archivio "Tela Umbra. Lini tessuti a mano dal 1908"

Romeyne had a strong and intense friendship and frequent frequentation with Alice Hallgarten Franchetti (New York, June 23, 1874 - Rome, October 22, 1911), attested by the writings and the diary of Mary Douglas Hamilton, an English pedagogist who collaborated with Franchetti from 1907 to 1910.

Alice, a New York Jew of Ashkenazi German origins, moved to Rome in the last years of the nineteenth century and married, on 9 July 1900, an Italian whom she met, dealing with social works: Leopoldo Franchetti (31 May 1847 - Rome, 4 November 1917), Sephardic Leghorn Jew, deputy and senator of the new United Kingdom.

Alice, like Romeyne, lived between Rome and Umbria, dedicating herself to sociohumanitarian and pedagogical works, with the aim of human and social promotion. It was Alice who introduced Maria Montessori to Romeyne, with the aim of promoting the Montessori Method, also sharing her pedagogical passion with her. ${ }^{5}$

Alice had founded the rural schools of Montesca and Rovigliano in Città di Castello between 1901 and 1902 and followed with interest the progress of the multi-class rural elementary school established at Pischiello on 19 December 1903 by the Marquise Sorbello.

\footnotetext{
${ }^{5}$ Nathalie Dana, Young in New York. A Memoir of a Victorian Girlhood (New York: Garden City/Danbleday C., 1963), 180.
} 


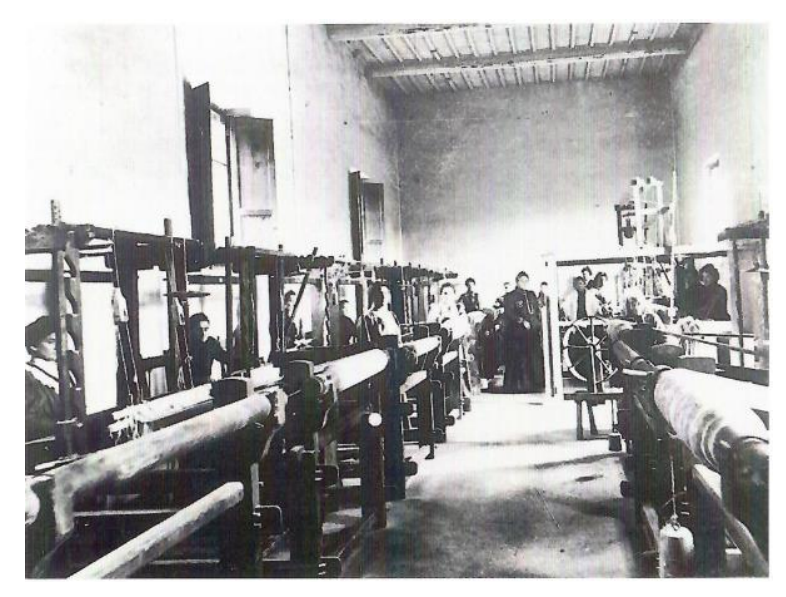

The Looms Room, Città di Castello, 1909 Archivio "Tela Umbra. Lini tessuti a mano dal 1908"

In 1908 Alice founded, also in Città di Castello, the Umbrian canvas workshop (since 2000: "Tela Umbra. Lini tessuti a mano dal 1908"), to preserve the ancient art of weaving and to give a dignified and favored work emancipation to peasant women, city washerwomen, and single mothers.

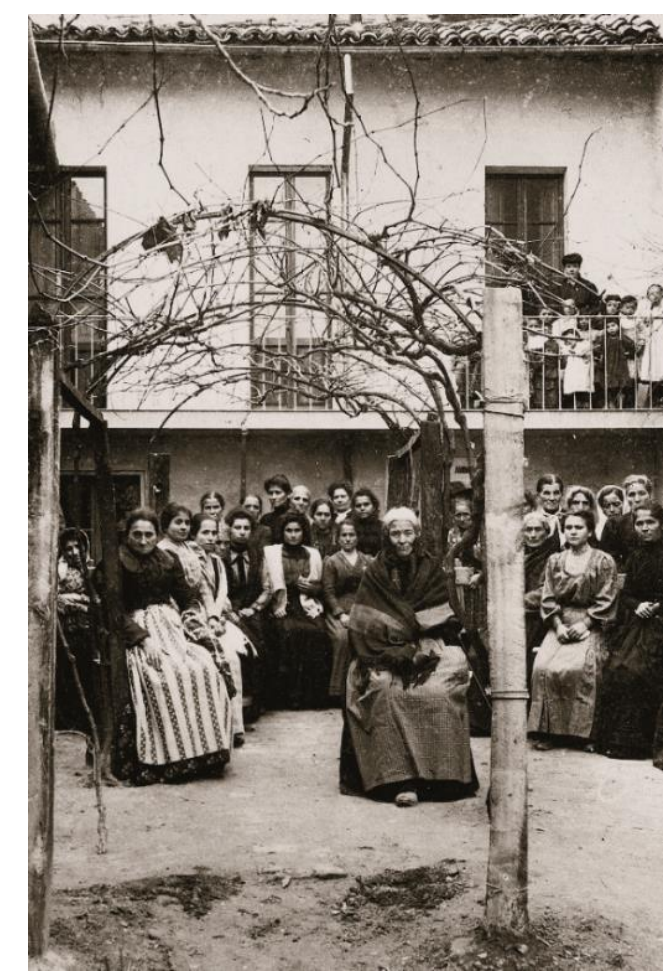

Workers of Tela Umbra with their children and the teacher of the company's kindergarten Archivio "Tela Umbra. Lini tessuti a mano dal 1908"

The workshop, which had a flexible schedule and an adjoining kindergarten, produced canvases for personal and home accessories, because there were very famous for embroidery. Romeyne used to buy large quantities of these canvases for embroidery and for this reason 
continued to go to Tela Umbra even after Alice's death, demonstrating fidelity in friendship and entrepreneurial collaboration. ${ }^{6}$

Others buyers of the canvases produced in the workshop of Alice were: Countess Edith Bronson Rucellai of Florence, president of the Tuscan Committee of the Industrie Femminili Italiane, linked to Carolina Amari and to the Trespiano school near Florence; Baroness Vittoria Luce Danzetta, who was a partner of Romeyne Robert Ranieri di Sorbello in the foundation of Italian Decorative Arts.
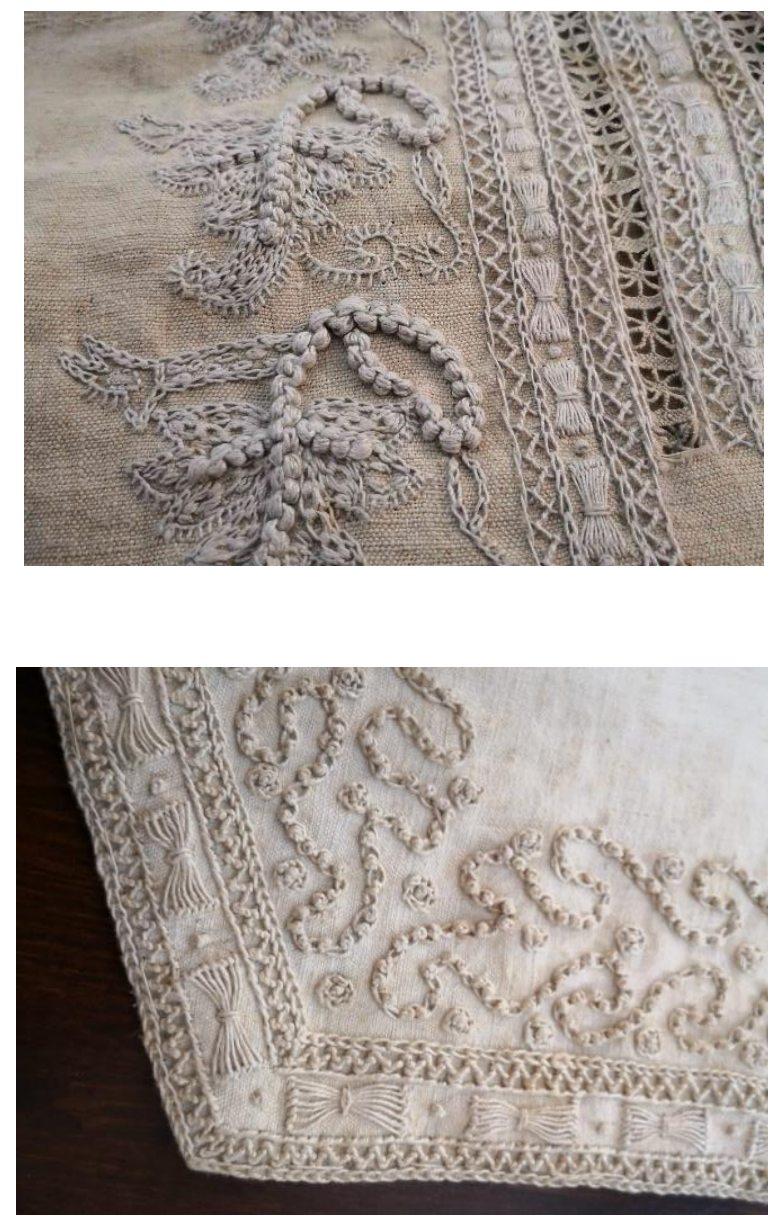

Pieces from the Ranieri di Sorbello School of Embroidery donated by the Fondazione Ranieri di Sorbello to the Tela Umbra Textile Collection "Tela Umbra. Lini tessuti a mano dal 1908", Città di Castello, 2000s

Marilena De Vecchi Ranieri di Sorbello (18 settembre 1921 - 3 settembre 2013) donated many pieces produced by the Ranieri di Sorbello Embroidery School: in 1979 to Cooper

\footnotetext{
${ }^{6}$ Maria Luciana Buseghin, La rete sociopedagogica di Alice Hallgarten Franchetti tra femminismo, istitutrici e maestre: Malwida von Meysenbug, Felicitas Buchner e Mary Douglas Hamilton, 107-138, in Governanti e istitutrici tra Ottocento e Novecento. Ruolo sociale e immagini letterarie/Governesses and tutors in the 19th and 20th Centuries, Atti del convegno, Perugia, 24-25 maggio 2019, eds. Isabella Nardi and Antonella Valoroso, Quaderni della Fondazione Ranieri di Sorbello n.7. (Bologna: Pendragon, 2020), 118-122.
} 
Hewitt Smithsonian Museum, New York; in 1997 to Museo del Tessuto e della Tappezzeria "Vittorio Zironi" ("Vittorio Zironi" Textile and Upholstery Museum) owned by the Municipality in 1997 but founded in 1966 as Museo Storico Didattico della Tappezzeria (Historical-Educational Museum of Tapestry) in Bologna; in 2000s to "Tela Umbra. Lini tessuti a mano dal 1908" (Umbrian canvas. Hand-woven linens since 1908), Città di Castello.

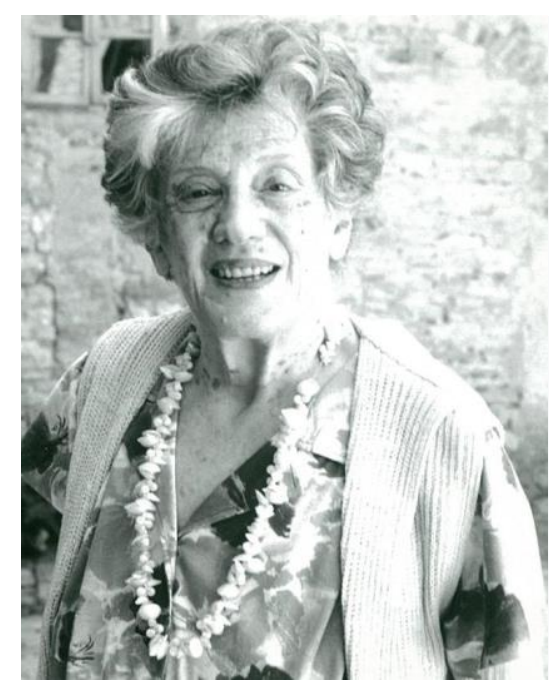

Marilena De Vecchi Ranieri di Sorbello (18 September 1921 - 3 September 2013)

Fondazione Ranieri di Sorbello Archive

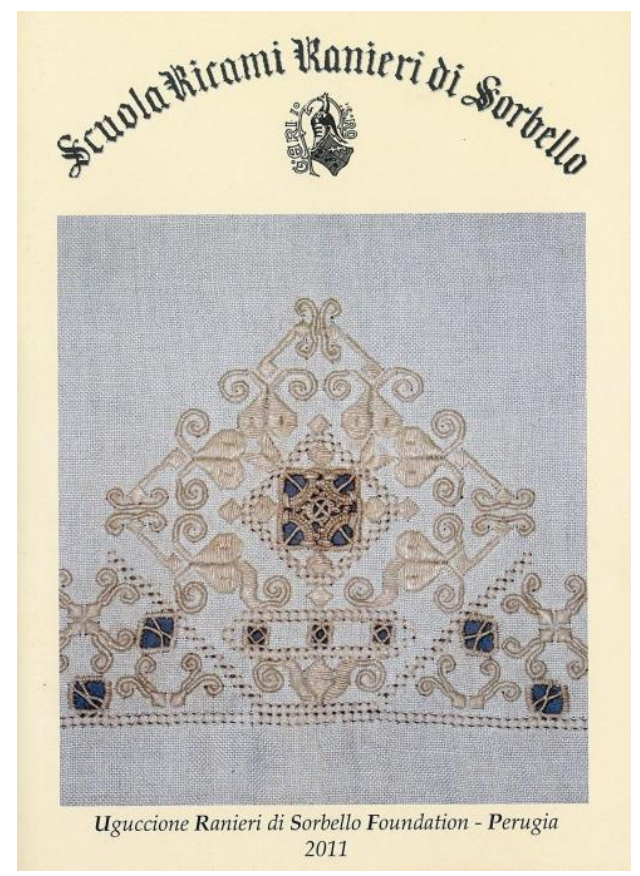

Marilena de Vecchi and Valentina Costantini, The Romeyne Robert Ranieri di Sorbello School of Embroidery: a textile workshop for women embroideries In Umbria (1904-1934) (Perugia: Uguccione Ranieri di Sorbello Foundation, 2011 
Bibliography

Bates-Batcheller, Triphosa B. Glimpses of Italian Court Life. Happy Days in Italia Adorata. Delhi, India: Facsimile Publisher, 2013 [1 ${ }^{\text {st }}$ published 1906].

Bistoni, Vittor Ugo. Grandezza e decadenza delle istituzioni Franchetti. Città di Castello: Edimond, 1997.

-----. Le scuole di Montesca e di Rovigliano. In Vittor Ugo Bistoni, Grandezza e decadenza delle istituzioni Franchetti. 94-189. Città di Castello: Edimond, 1997.

-----. Il Laboratorio Tela Umbra. In Vittor Ugo Bistoni, Grandezza e decadenza delle istituzioni Franchetti. 190-267. Città di Castello: Edimond, 1997.

Buseghin, Maria Luciana. Alice e la tela delle meraviglie/ Alice and the wonder wave. Città di Castello: Tela Umbra,1998.

-----. L'opera e la figura di Romeyne Robert Ranieri di Sorbello. 27-48. In Gianfranco Tortorelli (ed.) Ricami della Bell'Epoca. Foligno: Editoriale Umbra, 1996.

-----. Cara Marietta... Lettere di Alice Hallgarten Franchetti (1901- 1911). Città di Castello: Tela Umbra, 2002.

-----. I volti diversi del lavoro femminile: modelli di comportamento e pratica imprenditoriale nelle opere tessili in Umbria tra Ottocento e Novecento, 111-166. In Barbara Curli, Donne imprenditrici nella storia dell'Umbria. Ipotesi e percorsi di ricerca. Milano: Franco Angeli, 2005.

-----. Il Punto Sorbello, 103-104. In Marialisa Valoppi Basso (ed.), Filo, ricamo, nodi e colore. L'origine dei punti. Udine: Provincia di Udine, 2007.

-----. Alice Hallgarten Franchetti un modello di imprenditrice nell'Italia tra '800 e '900. Selci Lama: Editrice Pliniana, 2013.

- Arte tessile ebraica in Umbria tra XIV e XX secolo: note di ricerca e ipotesi d'approfondimento. In Paolo Pellegrini (ed.), Presenze ebraiche in Umbria meridionale dal medioevo all'età moderna. Atti della giornata di studi, Acquasparta, 12 giugno 2014. Foligno: Editoriale Umbra/Perugia, ISUC, 2017.

-----. Leopoldo Franchetti e Alice Hallgarten. Opere socio-pedagogiche tra Roma e Città di Castello, 241-259. In Sandro Rogari (ed.) Leopoldo Franchetti, la nuova Destra e il modello Toscano. Soveria Mannelli: Rubbettino, 2019.

-----. La rete sociopedagogica di Alice Hallgarten Franchetti tra femminismo, istitutrici e maestre: Malwida von Meysenbug, Felicitas Buchner e Mary Douglas Hamilton, 107138. In Isabella Nardi and Antonella Valoroso (ed.), Governanti e istitutrici tra Ottocento e Novecento. Ruolo sociale e immagini letterarie/Governesses and tutors in the 19th and 20th Centuries. Social Role and Literary Images, Atti del convegno, Perugia, 24-25 maggio 2019. Quaderni della Fondazione Ranieri di Sorbello n.7. Bologna: Pendragon, 2020. 
-----. Romeyne Robert in www.enciclopediadelledonne.it

Dana, Nathalie. Young in New York. A Memoir of a Victorian Girlhood. New York: Garden City/Danbleday C., 1963.

De Vecchi, Marilena and Costantini Valentina. The Romeyne Robert Ranieri di Sorbello School

of Embroidery: a textile workshop for women embroideries In Umbria (1904-1934). Perugia: Uguccione Ranieri di Sorbello Foundation, 2011.

Gori, Claudia. Crisalidi. Emancipazioniste liberali in età giolittiana. Milano: FrancoAngeli Storia, 2003.

Le Industrie Femminili Italiane. Cooperativa Nazionale Sede Centrale via Marco Minghetti Roma. Milano: Pilade Rocco e C. editori, 1906.

Laurenzi, Elena. I fili della trasmissione. Il progetto delle donne De Viti De Marco Starace nel Salento del Novecento. Lecce: Grifo (Cavallino), 2018.

Palomba, Ivana. L'arte ricamata. Uno strumento di emancipazione femminile nell'opera di Carolina Amari. Maniago (Pordenone): Le arti tessili, s.d. [2008].

Ranieri, Ruggero. Romeyne Robert Ranieri di Sorbello imprenditrice americana e le origini della scuola di ricamo e di merletto. In I talenti femminili alle origini dell'imprenditoria umbra. Atti del Convegno, 25-33. Perugia: Provincia di Perugia, 2013.

Scaraffia, Lucetta, and Isastia, Anna Maria. Donne ottimiste. Femminismo e associazioni borghesi nell'Otto e Novecento. Bologna: Il Mulino, 2002.

Speranza, Enrico. Le ricamatrici di Perugia, 293-296. In Massimo Mascini (ed.), L'Annuario del Lavoro 2018. S.1.: il diario del Lavoro edizioni, 2018.

Zironi, Stefano. Un Museo per l'Europa - Memorie e testimonianze da leggere e vedere del Museo Storico Didattico della Tappezzeria. Bologna: Grafis - Industrie Grafiche, 1996. 